\title{
Feudal colonisation and socio-ecological transition in Mayûrqa (Muslim Majorca) in the thirteenth century
}

\author{
RICARD SOTO COMPANY ${ }^{1}$ AND ANTONI MAS FORNERS ${ }^{2}$
}

ABSTRACT. The feudal colonisation of the Island of Majorca, traditionally considered part of the Spanish 'Reconquista', must be included in the greater process of European feudal expansion. The island was inhabited by people living in a Muslim society, not a feudal one. The conquest by Catalan lords meant the imposition of a new feudal class structure and a new use of natural resources on the conquered land. We summarise the composition and evolution of the three main components of this topdown imposed feudalism: the Muslim populations conquered and enslaved, the Catalan settlers and the entirely new agricultural landscape they created.

\section{INTRODUCTION}

Traditionally, historians have argued that the Christian conquest of the Iberian Peninsula under Muslim rule (Al-Andalus), completed in 1492, consisted essentially of a recovery ('reconquista') of lost territories. The term 'reconquista' is controversial, since it is ideologically charged to describe lands lost centuries earlier as being 'recovered'. This idea of a 'reconquista', prevalent until the last quarter of the twentieth century, minimises the effects of the conquest on Muslim society and stresses continuity rather than change. Associated with this view is the idea that settlement after the conquest relied on the conversion and integration of the pre-conquest population, rather than on Christian settlers. By contrast, more recent studies argue that the conquest of al-Andalus was part of the process of European expansion (or formation of Europe, in the terms in which this process has been characterised by Robert

\footnotetext{
1 University of Barcelona.

2 University of the Balearic Islands.
} 
Bartlett) which began in the tenth century. Our approach is in line with Bartlett's view and stresses that this expansion was dependent upon the ability to conquer, disrupt and even destroy the population that had previously occupied the land over three centuries. We also argue that the success of colonisation could only be guaranteed by the immigration of Christian settlers in sufficient quantities to replace all or part of the conquered Muslim society. From this it follows that the Catalan conquest of Majorca should be seen as a manorial frontier expansion followed by a process of settlement by peasant colonisers. ${ }^{1}$

The aim of this article is to offer an overview on how feudal colonisation changed the prevailing farm systems in the island of Majorca, seen as part of the general process of European feudal expansion. It draws in part on original research, and in part on a synthesis of published work by ourselves and other scholars, but not hitherto available in English. Our research draws in particular on registers (Escrivania de Cartes Reials) of several thousands of surviving notarial documents, compiled between 1298 and 1311 by the agents of the Crown in an attempt to preserve documents relating to the earliest years of the conquest. ${ }^{2}$ The documents themselves record transactions dating from 1230 to the start of the fourteenth century, covering land belonging to the Crown and the nobility, which was most of the island. These documents include sales of land, slaves and real and manorial incomes; contracts for transporting goods, loans, liabilities and more. Our core database is a case study of the Valldemossa-Bunyoles district, consisting of some 850 documents.

The conquest of the Balearic Islands (Majorca in 1229, Ibiza in 1235 and Menorca in 1287) by the feudal militias of Catalonia and Aragon, accompanied by some urban players and led by the Crown, has been included in the so-called Spanish Reconquista, or rather 'conquest of al-Andalus', the name given to the area of the Iberian peninsula and southern France under Muslim rule for all or part of the period 711 to 1492 . In turn, the conquest of al-Andalus can be seen as part of a more general process of European feudal expansion. ${ }^{3}$ The lands on which this expansion took place were by no means vacant. They were inhabited by communities without any feudal structure in the form of landlords or transfers of rent, or with lower degrees of feudal organisation than their invaders. ${ }^{4}$ In many cases, rather than the hierarchical structure of 'orders' (lords, peasants and warriors) that came to characterise feudal society, these lands had a social organisation based on tribal or clan structures. The conquest therefore involved the imposition, overseen by the nobility, of imported feudal structures onto the conquered societies and the lands they had theretofore owned. The new feudal ruling class did not favour reproduction among the remaining defeated local population in Majorca. ${ }^{5}$ Instead, the conquerors encouraged new Christian immigration by means of offering land to subsequent generations of settlers from the peninsula, and 
reducing or abolishing certain manorial rents and jurisdictional burdens to which this land was subject. This frontier institutional framework culminated in the so-called Charter of Enfranchisement (Carta de Franquesa), a set of rights granted by the king in 1230 with the clear intention of attracting settlers to Majorca. These rights were initially granted only in the king's own domains, but later took effect throughout the island, including territories under manorial rule. All of this was carried out while retaining the basic structure of the feudal system, in terms of rents provided by those who farmed the land, either as portions of harvests, yearly payments in cash, or fees attached to property transactions and inheritances.

Feudal lords, by their very essence, always depended on subordinate peasants to generate the main share of their feudal rents - sometimes combined with other forms of income provided by slaves or seasonal agricultural labour. There were, however, several ways to create a subordinated peasantry, as Bartlett has shown. ${ }^{6}$ Sometimes indigenous peasants were placed under the manorial control of landlords, as in the Balto-Slavic fringes. This happened where the conquered societies could be culturally 'assimilated', as well as subjected. Sharing the same Christian religion might favour assimilation - although local institutions based on the Church could help to resist conquest and absorption, as in the Kingdom of Poland. However, when indigenous societies were solidly structured around alien forms of social and religious organisation, as in the case of the Balearic Islands, the conquerors faced many problems in enforcing new feudal rules. It was then that the possibility arose of replacing them with peasant settlers from areas formerly under feudal control. $^{7}$

The key factor in the expansion of feudalism into Muslim lands, as in the principalities of the East and al-Andalus, was the availability to feudal conquerors of a large number of settlers from areas already under feudal control who were ready to repopulate the land and thus supplant or at least firmly subordinate the native inhabitants. In the feudal colonisation of Palestine during the first Crusades the Frankish lords replaced the local government only in the collection of taxes, but failed to introduce new forms of income distribution similar to those of French feudalism. ${ }^{8}$ This lack of imposition of feudal structures was rooted in the conquerors' inability to change the prevailing land uses and farming systems of the local peasants (fellahin). Some of their crops, such as cotton, sugar and saffron, would become highly profitable to the western lords as easily marketable products in European markets. ${ }^{9}$ But large-scale grain and wine production, which Bartlett sees as characteristic of the expansion of European feudalism, faced considerable resistance from a local population, which, in turn, could rely on the strong resilience of traditional agro-ecosystems tightly interwoven with climate and soils quite different from Western Europe. ${ }^{10}$ 
There were several advantages for feudal lords in the relocation of peasant settlers where this was possible. First, the settlers provided a religious doctrinal reliability by which they could easily be turned into foot soldiers in a 'Holy War'. Second, accustomed as they were to the feudal system, they would be easily subjected to the new land distribution bound to manorial rents. They could be enticed to resettle with the offer of generous allotments of land and lighter feudal burdens compared with the areas they left behind. Finally, they brought with them market-oriented skills in farming vines, olive trees or even grain.

The medieval conquest and colonisation of Majorca is a good example of how extraordinary the conquest of al-Andalus was within the broader European feudal expansion. Al-Andalus was a developed society with a strong state based on taxation in which the majority of the population and their leaders were Muslim. Once most of the Iberian Peninsula had been brought under their rule, especially in the wealthiest and most populated areas, al-Andalus became the dominant power in the face of small, aggressive Christian kingdoms and counties in the North of Iberia until the twelfth century.

The balance of power started to shift in the eleventh century, following the disintegration of the Andalusi Caliphate of Cordoba into a series of smaller states (Taifa) on the one hand, and the completion of the feudalisation process in the northern Christian societies on the other. There, a warrior class of landed nobles, mainly composed of lords and knights, lived off feudal levies paid by the inhabitants of their domains, which they longed to expand through the conquest of territories in al-Andalus. The feudal conquest of al-Andalus would provide these noble classes with fresh spoils in the form of lands to enlarge their property holdings.

The Reconquista thus sought to defeat a richer, long-established society with a distinctive Muslim culture. It is not surprising that the great campaigns of this conquest launched after the dissolution of the Caliphate (1031) were led by the Church and the kings of Castile and Aragon (that includes Catalonia). The history of the conquest of al-Andalus is marked by interruptions and setbacks, such as the temporary Muslim reunification led by two African groups, the Almoravids and the Almohads. But in the long run this feudal conquest neither came to a complete standstill nor changed in terms of the social and cultural features of Christian colonisation.

Partly because the territory of al-Andalus previously had been occupied by Christian populations, and it continued to share a religious border with the northern feudal kingdoms, the ideological legitimacy of the conquest was similar to that used in the Crusades - including papal support. As described above, however, the process of conquest and settlement was very different in Palestine and in al-Andalus. In the case of al-Andalus the conquest led to a complete destruction of the Andalusi society. A new kind of social fabric, 
which roughly reproduced those of the conquerors, arose from this tabula rasa.

A conquest and colonisation like this, which eliminated most of the potential rent-payers, would have been impossible if the conquerors had not been able to rely on a significant population of settlers willing to immigrate and occupy the newly conquered lands. The geographical proximity to the newly invaded territories facilitated these immigration and colonisation processes. The settlers shared the same religion with the conquerors and were accustomed to life under feudal rule. That meant paying manorial charges to the landlords, and reorganising the exploitation of natural resources for that purpose. Therefore the settlers had to transform the prevailing landscape into a new one suitable for the aims of feudal noblemen. This kind of colonisation entailed a true cultural disruption as well as profound socio-ecological change. Both factors ensured that the small remaining patches of Andalusi population would not be a likely source of rebellion. From this standpoint Majorca is one of the clearest and best-documented cases of conquest and colonisation of al-Andalus followed by a replacement of the population.

\section{THE FATE OF THE PRE-CONQUEST POPULATION: EXTERMINATION,}

\section{ENSLAVEMENT AND CONVERSION}

The destructive violence of the invasion of Balearic Islands, as opposed to other Catalan-Aragonese conquests which ended in negotiated surrender, as in Tortosa or Valencia, sealed the fate of the indigenous population. ${ }^{11}$ Unlike Valencia, in Majorca there were no aljahames, self-governing communities of Muslims, and the post-conquest documents contain no reference to any treaties. According to one chronicle, the Llibre dels Feyts, ${ }^{12}$ thought to date from before 1276, the indigenous people captured in the town of Ciutat de Mallorca (now the capital Palma) were auctioned off, and the same happened to those who resisted. The chronicle also states that King Jaume I promised Xuaip, the leader of the refugees in the mountains, that if they surrendered they could populate the island. Some accepted the offer, but the rest, about 2,000, resisted until they were defeated. ${ }^{13}$

Those who survived the killing were almost all enslaved and sold in a thriving trade. ${ }^{14}$ Since most of the recorded sales of slaves were for single individuals it is safe to assume that families were broken up. There was also a major 'export' of indigenous Muslims, documented in the first decades after the conquest. The geographic dispersion of the survivors led directly to a drop in reproductive rates, causing demographic collapse and thus further destruction of the Andalusi social fabric. ${ }^{15}$

The Muslim society was then completely displaced by several large waves of settlers who arrived in Majorca from the continent, turning the remaining 
original inhabitants into a minority of outsiders in their own country. A few were baptised and converted to Christianity, probably in the hope of obtaining freedom. ${ }^{16}$ Whether to grant freedom, however, was the master's decision. In some cases it was granted without demanding payment, but more often it was in exchange for a rent stipulated in contracts known as talla or alforria. Many Muslims known as alforre, or sometimes baptizatus or batiat (baptised), acquired semi-free status which lasted until the owner had been paid the amount fixed as the price for release. ${ }^{17}$ In rural areas there were Andalusi people known as tallats (subject to a talla contract), who usually received land under lease which they had to return upon completion of payment for their freedom. Those who achieved freedom had two options: emigrate to another Muslim society or stay in a Majorca ever more densely populated with Christian settlers.

The available data contradict the old belief that, through a process of conversion and integration, Andalusi people formed the core of the post-conquest Majorcan population, since the number of Christian settlers would have been insufficient. In previously published research, we found fewer than a thousand references to Andalusi, and most of them were slaves. ${ }^{18}$ Other calculations focusing on the City of Majorca and different rural communities show that Andalusians, including slaves and free batiats, never reached 10 per cent of the total population. ${ }^{19}$ The Arabic language disappeared, and those who had been baptised were completely assimilated in less than 70 years. Social pressures drove them to abandon their language, their culture and their religion in order to embrace those of the conquerors.

The speed of this assimilation contrasts with the case of Sicily, where the process lingered on for some three centuries. In a direct comparison between the Muslims of Sicily and the Andalusians of the Crown of Aragon, Jacques Heers notes that the decisive factor in the assimilation of the indigenous population was the intensity of Christian immigration. ${ }^{20}$ Therefore, the speed of the acculturation of the Majorcan batiats was due to their becoming a demographic minority. Although their marginalisation was perhaps not as overwhelming as the historical sources suggest, it was in any case enough to cause the disappearance of Andalusi culture before 1300.

\section{THE AGRARIAN LANDSCAPE OF $M A Y \hat{U} R Q A$}

As we have shown in previously published work, the new colonisers profoundly transformed agrarian production on the island. From the evidence of rents, which were paid in kind, we know that most land was devoted to grains (mainly wheat and barley). Livestock also spread throughout the island, taking advantage of depopulation following the conquest, and there was also an expansion in vine and olive cultivation, while irrigated crop production 
was limited to small family farms. While aspects of the socio-ecological transformation are still debated, it is clear that overall the conquest was highly disruptive of existing crop patterns and farming techniques. In this next section, we provide an overview of the state of farming on the island prior to the conquest.

When the Muslims arrived in the Balearic Islands, they brought with them very specific farming systems widely practised in al-Andalus and the Maghreb, specific in terms of both techniques and social organisation. This type of agriculture, the predominant choice for groups of tribal or clan origin, involved the combination of intensive irrigation with extensive livestock. Extensive cereal farming, predominant in European agriculture, had only a minor role, being relegated to the margins of irrigated farms. ${ }^{21}$

The socio-institutional foundation of Mayûrqa, and the other Balearic Islands, comprised a multitude of farms known as alquerias and rahals. The Llibre del Repartiment, a register compiled in 1232 soon after the Conquest of all these farms owned by the king (about half of all farms on the island), shows that there were about 1,500 in Mayurqa. ${ }^{22}$ They averaged 7 jovades in size: 11 for the alquerias and 4 for the rahals. ${ }^{23}$ The alqueria, as defined by Pierre Guichard, was a settlement made up of peasant farmers of common tribal or clan origin. ${ }^{24}$ The rahals, on the other hand, were private farm holdings, farmed by single families and mostly located near towns. ${ }^{25}$ In the case of the Balearic Islands, however, this definition does not fit. In Mayûrqa the term alqueria, rather than a settlement in an inhabited place, designated a broad area of several square kilometres where the cultivated area was just one or two hectares, usually concentrated in a single place or resulting from the construction of irrigation systems, and where there may have been more than one residence. These settlements could be very small. ${ }^{26}$

This farming system had assimilated diverse agricultural traditions - for example, Mediterranean, Mesopotamian, Indian. Indeed, it had introduced a large number of crops from what authors such as Lucie Bolens and Andrew M. Watson have called Nabatean agriculture, including sugarcane and many fruit trees. ${ }^{27}$ The existence of these crops, along with the sophisticated irrigation technology described below, has led some authors to argue that there was an agricultural revolution between the eighth and tenth centuries in the Islamised world. Others minimise this impact, pointing out the existence of many of these species in Roman agriculture, as described in the works of Columella. More recently, Michael Decker has argued for the important influence on Islamic farming techniques of previous Roman, Greek and Sassanid farming systems, and reinforces the claims of earlier scholars who attribute irrigation systems in al-Andalus to the Romans. ${ }^{28}$

It is true that the farm systems introduced by Arabo-Muslims in the western Mediterranean were to a large extent a continuation of Roman agriculture. 
Extensive grain cultivation remained in place, as well as the cultivation of olive trees and vineyards, particularly in the peninsular areas of al-Andalus. The Koranic prohibition against wine was not always respected, and the consumption of grapes, either fresh or dried, was very common. Nevertheless, a new agriculture based on fruits and vegetables acquired an importance theretofore unknown. This new horticulture, both for consumption within small farming communities and for sale at local markets or for export abroad, was highly successful.

In the peninsular al-Andalus, cereals remained the predominant crop, but in Mayûrqa the actual extension of this production is still under debate. According to Helena Kirchner, cereal was produced only in the irrigated areas of the alqueries, whereas dry farming was scarce and associated only with areas of extensive husbandry. ${ }^{29}$ However, it is difficult to determine exactly what kind of cereals were cultivated: wheat and barley were, of course, produced everywhere, but presumably also cultivated species of Asian or African origin, such as sorghum or millet, ${ }^{30}$ which were resistant to the extreme Mediterranean dryness. In addition, in the wet areas like the Albufera lake in the north-east, rice was a common crop, as in Valencia. ${ }^{31}$

Adapting these horticultural crops to al-Andalus where soils and climates differed from their origins was an enormous task. Climate in the Balearic Islands was free from severe frost, and was warm enough for almost all tropical and subtropical species introduced by the Arabo-Muslims to thrive. The chief problem was aridity: almost all these species flower at the time of year that corresponds to the western Mediterranean dry season. The solution was artificial irrigation. The tremendous advances Andalusi agriculture made in irrigation remains undisputed, despite the recent debate regarding the scope of irrigation during Roman times. ${ }^{32}$ This was achieved by implementing irrigation techniques which were very simple and relatively inexpensive in terms of labour, tools and design.

Bolens, Watson and other authors point out the role of adaptation of exotic plant species in relatively complex irrigated plots in the gardens of royal palaces, particularly during the Taifa period. Public initiatives were also important in the design of irrigation works along the major river systems, such as the Xúquer, Turia and others in south-eastern Andalus. But in other areas of al-Andalus, such as inland Sharq al-Andalus, irrigation was rather the outcome of many small initiatives designed to exploit very limited water resources. This was also the case in the Balearic Islands, where the only river is the Santa Eulalia in Ibiza. The only source was groundwater, very abundant in areas of karst limestone soils (most of Majorca is karst).

The underground water collection system used by the Muslims in the Balearic Islands is now well known thanks to the research done by Miquel Barceló, Helena Kirchner, Mercé Argemí, Félix Retamero and others. ${ }^{33}$ 
Prior to Barceló's pioneering work in the 1980s, this technological heritage was utterly unknown, despite the fact that some of the original reservoirs were still in use. The key breakthrough was to link these reservoirs to qanâts. The qanât, depicted in Figure 1, was a water-mining technology of Iranian origin, which spread westward with the Arabo-Muslim expansion. From Iran to al-Andalus, including Yemen and the Maghreb (where they were called foggara in the Amazigh language), these qanâts were the primary means of collecting water for small farms lacking other irrigation sources. They have tended to be overlooked in the literature as they were modest constructions compared with larger public or royal irrigation systems. Their small size, which at best featured excavated galleries of little over 100 metres and irrigated areas ranging from 0.5 to 2.5 hectares, made them especially adaptable to small settlements. Indeed, a specialist and a few farmers with simple tools could build a qanât. The trickiest part, requiring more skills, was to adapt the technology to specific local conditions of water availability: the flow (and its seasonal variations), slopes and soils. ${ }^{34}$ Only locals could acquire such expertise and design them from inception. The irrigation systems in the other Balearic Islands were quite similar to those of Mayûrqa, but even smaller. ${ }^{35}$ Scholars underline the 'rigidity' of these systems, given that once designed and built they could not be expanded - although they did support subsequent overlays. We can assume that after its construction a qanât irrigation system would not be expanded, and thus we can estimate how many people it could support. ${ }^{36}$

A socio-metabolic result of this Muslim technology was a diet much more centred on fruits and vegetables than in traditional Mediterranean and European societies. Documents written immediately after the Catalan invasion describe the richness of horticulture in Majorca and mention mulberries, dates, beans, peas, onions, garlic, cabbage, asparagus, cherries, plums, pomegranates, pumpkins, cucumbers, apricots, apples, peaches, orange, lemons and citrons. ${ }^{37}$ Pepper (piperis) is mentioned as payment for a lease, clearly meaning ground dried pepper. Industrial crops were also quite important. Flax and hemp were very often mentioned in land leases between Catalan lords and settlers, and we know that textile manufacturing, including cotton, was important in Madîna Mayûrqa (Ciutat de Mallorca, now the capital Palma). Mulberry tree cultivation for silkworm breeding was also known - at least around the palace of Almudayana. There is a mention of an alcaicería, a silk market, in the city of Majorca, ${ }^{38}$ although the twelfth-century traveller al Zuhri claimed silk production was unknown in the Balearic islands. 39

In contrast to the descriptions from the twelfth century, thirteenth-century Majorcan documents mention above all wheat, vineyards and olive trees. The olive tree was cultivated before the Christian conquest, and thriving olive groves could be found in various parts of the island, notably in the 


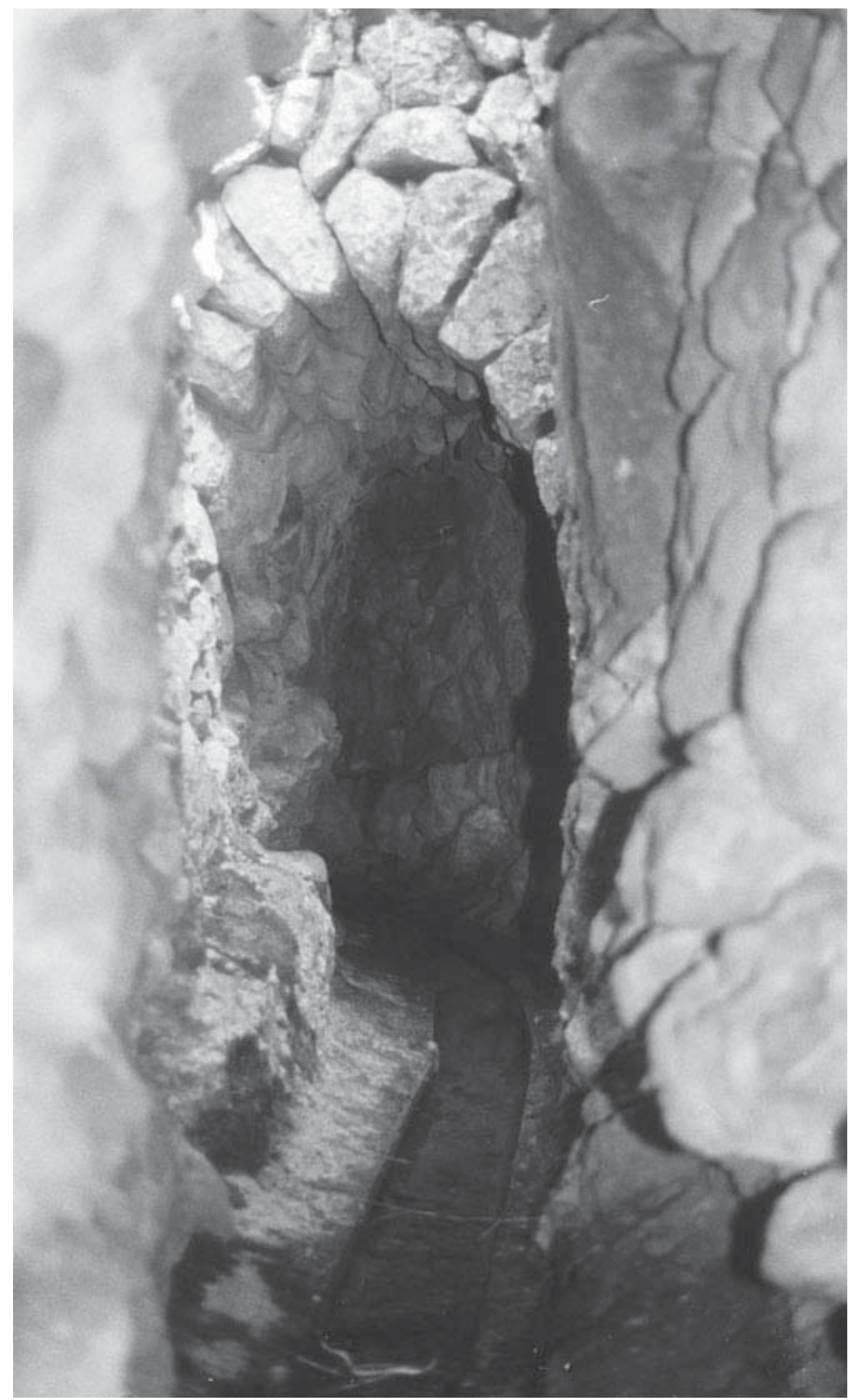

FigURE 1. Inner of a qanât in Bunyola.

juz' (district) of Bunyûla-Mûsu (Figure 2) and the alqueria of Biniatzar. Olive groves are mentioned so soon after the conquest that they cannot be attributed to any innovation by the early Christian settlers - olive trees need at least eight years after grafting before starting to produce. The wild olive tree is native to the island, and very possibly the cultivation of olive orchards spread during the 


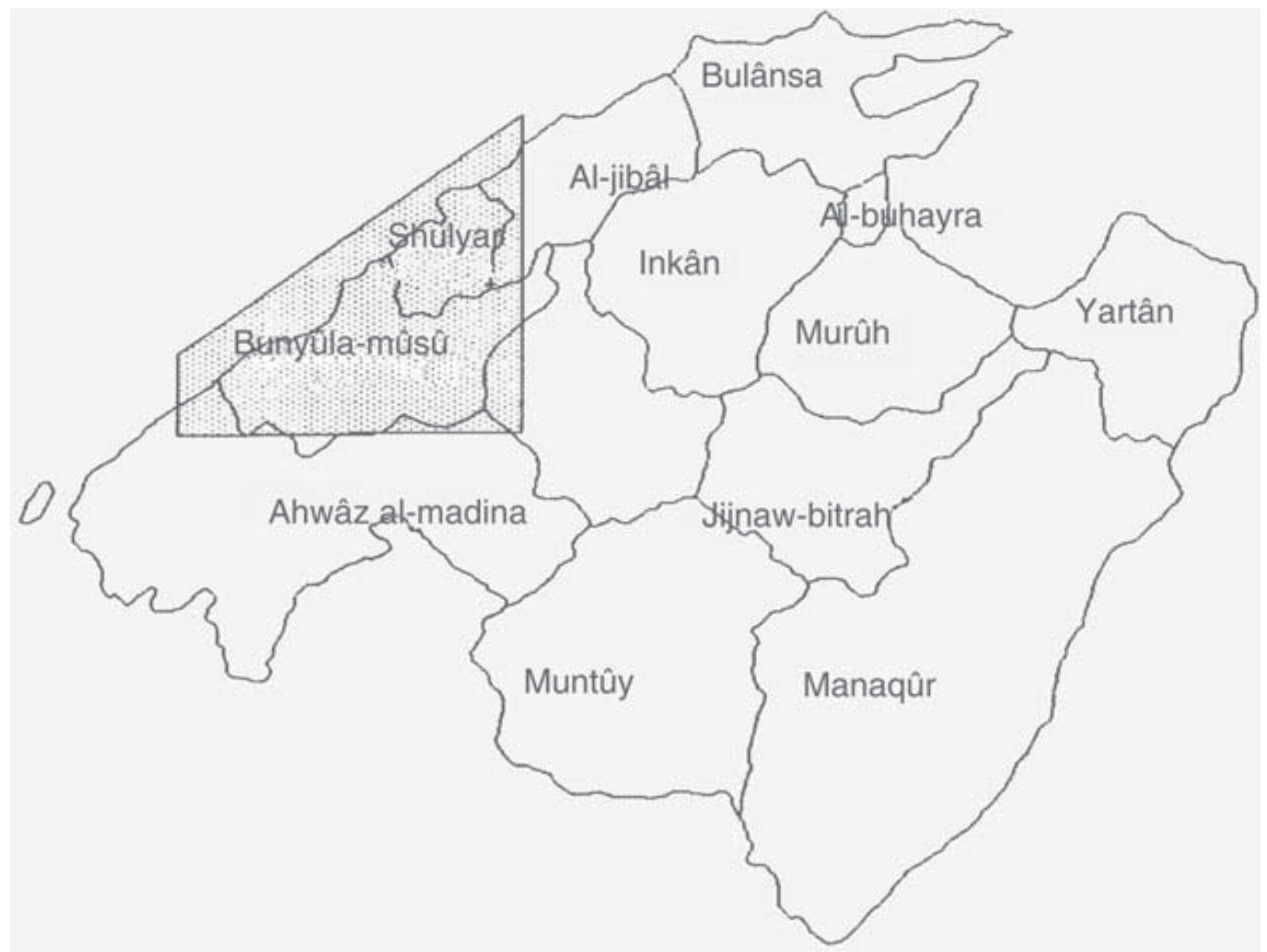

Figure 2. Districts (ajza') of Mayûrqa. The area of study is in grey. Source: J. Jover and R. Soto, 'De l'agricultura andalusí a la feudal: ¿una ruptura agroecológica? (Mallorca 12301350)', in A. Sabio and I. Iriarte eds., La construcción histórica del paisaje en España y Cuba (Zaragoza, 2003), 25-52.

reign of Banû Ghaniyya, between 1126 and $1203 .{ }^{40}$ Trade was greatly hindered between the eastern islands and the rest of al-Andalus, particularly with the main oil-producing regions, after the Almohads conquered Granâta in 1157-1158. This would explain the previous absence of olive trees, as noted by Arab travellers, and their subsequent significance.

Livestock also predated the conquest. In Muslim documents, Mayûrqa was divided into 12 or 13 districts called ajza' (plural of juz'; Figure 2). This term, which differs from that commonly used in al-Andalus (iqlim), refers to a pastoral area devoted to livestock-raising. Although the use of the term has sometimes been considered to be an archaism, it reflects the importance of livestock-raising on the island. As early as the tenth century, the traveller Ibn Hawqal mentioned the abundance of horses and mules on the islands, echoed four centuries later by the scholar Ibn al-Khatib. ${ }^{41}$ Regarding the largest island, he mentioned its wealth of livestock, particularly sheep, oxen and horses. Based especially on the writings of Ibn al-Khatib, and the study of local flora, Angel Poveda has suggested a specialisation in mules in the district of Jijnau-Bitrah. ${ }^{42}$ Guillem Rosselló, based on an episode described by the 
scholar and diplomat Ibn al Abbar, ${ }^{43}$ has similarly argued for the existence of a large footwear manufacturing industry on Majorca. ${ }^{44}$ The importance of livestock before and after the feudal conquest seems unquestionable.

It also seems that the large districts of Manaqûr and Muntûy (see Figure 2), where climate and soils are good for open pasture, were devoted to extensive livestock grazing. In other districts, however, the prevailing land-use pattern seems to have been a sharp divide between scattered horticultural rings or strips around small-scale hydraulic systems surrounded by an extensive land matrix of uncultivated open pastures, woodlands and scrub. Between the edges of both there were some areas of rain-fed crops, cotton and flax, or even forage. Thus, the importance of livestock and pastureland might be taken as evidence of a Muslim farming system in which extensive grain farming was relatively rare, as suggested above. This is controversial, however, because the image of Majorca from the late middle ages remains that of a society focused on grain production. Studies based on extensive archaeology have not found solid evidence of grain farming before the conquest outside the irrigated perimeters of Muslim settlements. However, if rain-fed grain farming did exist in Mayûrqa, it would be more difficult to trace archaeologically than irrigated lands - and we should recall that most of the reliable information we have in this regard comes from archaeology. ${ }^{45}$

Moreover, although the polyculture of irrigated orchards allowed for a more varied diet than exclusive grain farming, grain consumption, both by humans and by animals, remained important. This grain could be derived from three possible sources, not mutually exclusive. First, irrigation may have enabled high productivity in grain intensive farming. Second, grain could have been imported by sea and paid for with exports of manufactured products and livestock. Third, there may have been more extensive rain-fed grain farming, as discussed above. The question of grain production thus remains an aspect of this Muslim society that merits further study, compared with other aspects that are now quite well understood.

\section{REPOPULATION AS COLONIAL IMMIGRATION}

Having described both the fate of the indigenous population and the reorganisation of the agrarian landscape, this section discusses the repopulation of the island in terms of who the settlers were, the pace of repopulation and the ways in which repopulation can be described as a process of feudal expansion. Both the pace and nature of repopulation have implications for the social differentiation that can be detected among the peasantry by the end of the thirteenth century. There is a longstanding consensus among historians that the majority of immigrants who settled Majorca after the feudal conquest came mainly from Catalonia, particularly from the north-eastern Catalan lands in the Bishopric 
TABLE 1

Origins of the settlers of Mallorca (thirteenth century) (\%)

\begin{tabular}{lcccc}
\hline \hline & & & \multicolumn{2}{c}{ In different places of rural Majorca } \\
\cline { 4 - 5 } Coming from & In all Majorca & In the City of Majorca & Manacor & $\begin{array}{c}\text { Muro-Santa } \\
\text { Margarida }\end{array}$ \\
\hline Catalonia & 77 & 75 & 80 & 90 \\
Occitania & n.a. ${ }^{a}$ & 10 & 11 & 6 \\
Aragon & n.a. & n.a. & 7 & 1 \\
Other or unknown & 23 & 15 & 2 & 3 \\
Total & 100 & 100 & 100 & 100 \\
\hline \hline
\end{tabular}

${ }^{\text {a }}$ Not applicable.

Sources: A. Mas and R. Soto, 'Un regne dins la mar: el procés migratori català i l'extinció de la població indígena a Mallorca', L'Avenç 290 (2004), 35-9; A. Mas, 'Aportació al coneixement de les característiques i dels ritmes de la immigració colonial al Regne de Mallorca durant el segle XIII', in M. Barceló ed., El Regne de Mallorca: crülla de gents $i$ cultures, segles XIII-XV (Palma, 2007), 283-326; A. Mas, 'Les Ordinacions de Jaume II: construint un país o administrant el patrimoni del rei?', Lluc: Revista de Cultura i d'Idees 816-817 (May-August 2009), 27-32; A. Mas, 'El procés repoblador a Mallorca durant la primera meitat del segle XIV. Una aportació al seu estudi', Butlletí de la Societat Arqueològica Lul-liana 50 (1994), 167-98.

of Girona, followed in importance by Occitania, Aragon and other places such as the Italian republics and even from inland Iberian regions like Navarre. ${ }^{46}$ The disagreements lie in the relative size of the immigration from these different places. Documents from the time, including the Escrivania de Cartes Reials on which most of this article is based, are not often explicit about settlers' origins and we must rely on onomastics to identify toponymic surnames (place names, of cities and regions, which became family names) among a large portion of settlers.

Recent studies based on reliable samples of toponymic surnames show that the settlers in Majorca were mainly Catalans (see Table 1). Despite the predominance of surnames from areas of Girona, during the initial settlement there was a greater diversity of origins from within eastern Catalonia. Immigration followed the same pattern until the Black Death. After 1348, the rural areas of Majorca continued to receive settlers from the north-eastern regions of Catalonia, most of them agricultural labourers and small peasants (emfiteutes) with land held on emphyteutic leases..$^{47}$ Emphyteusis, a particular feature of Mediterranean feudal society, and one of the feudal structures introduced by the conquerors, implied the cession of use-rights over small plots of land by the landlord (usually at this date the Crown, nobility, or ecclesiastical institutions) to a peasant cultivator, in return for fixed rents of different kinds. 
The peasant, however, had the right to sell, sublet or transmit these rights via inheritance, subject to payment of a fee. Meanwhile, the City of Majorca continued to attract traders and sailors from Catalonia and other parts of the Mediterranean (Italy, Occitania). Manufacturing activities also attracted immigrants: of the 101 wool-working apprentices registered in the city between 1336 and 1338, 60 were natives of the Kingdom of Majorca, 37 were from Catalonia, 3 from Valencia and 1 from Occitania. ${ }^{48}$ It is also important to note the presence of Jews among the island's settlers, particularly in the city. Although Jews were also given land in rural areas, it seems most likely that they settled within Christian communities. They worked in primarily urban activities, although we do find some involved in the expansion of olivegrowing or the purchase of royal rights in the countryside. ${ }^{49}$

Settlement began as an urban colonisation, not only in terms of its location in the first decades after the conquest, but also in the role the city played as the centre of the colonisation of the rest of Mayûrqa. Ciutat de Mallorca was the main entry point to the island, before many of the earlier settlers established themselves in the countryside. This is clearly documented in the land register, the 1232 Llibre del Repartiment, mentioned above, and other sources, such as a total of 627 people mentioned in the manorial accounts (capbreu) of the urban properties of Nunó Sanç recorded from 1232 to $1240 .{ }^{50}$ Assuming that other properties would have had similar numbers of occupants, the urban population was already quite large just a decade after the conquest. The king, businessmen and other beneficiaries not normally residing in Majorca also had their attorneys in the city to manage their estates in the rest of the island.

Rural settlement was quite another matter - even if the differences between different areas of Majorca must be stressed. As far as we know, inland settlement remained very weak a decade after the conquest. ${ }^{51}$ Only with the continued arrival of immigrants from the continent up to the first half of the fourteenth century did inland settlement gradually become denser. There is evidence of these arrivals of new settlers, such as the greater number of leases of royal rights, which indicates a growing rural population. Nevertheless, there were large geographical imbalances. While vine-growing areas not far from the capital Ciutat de Mallorca became densely populated relatively quickly, such as the villages of Valldemossa and Bunyola, colonisation was slower in the eastern districts of the island that were generally drier and less suitable for rain-fed farming (like the former juz' de Manaqûr). ${ }^{52}$ Settlement was also slower in some localities in the inner central plain, such as Sineu and Muro, than in other, relatively distant areas, like Pollensa. ${ }^{53}$ Despite these local differences, by the end of the thirteenth century Christian settlers had occupied the entire countryside and enlarged the agricultural areas of the Muslim period with the expansion of lands devoted to rain-fed grain farming. The success 
and continuity of these settlements are another matter, as not all settlers met their goals.

As far as we can tell from the series of documents in the Escrivania de Cartes Reials, which essentially reflect the growth of the Crown's administration, the pace of the repopulation process varied over the thirteenth century. ${ }^{54}$ There were two large waves, one between 1232 and 1250 and another in the late thirteenth century. ${ }^{55}$ The first wave met with certain success, as it left a stratum of firmly established population. Written sources indicate a slowing in the pace of settlement during the second wave in the late thirteenth century, however, suggesting that a saturation point had been reached. Immigration slowed, but it did not stop. Álvaro Santamaría estimated the population of Majorca at some 60,000 residents in 1329, based on data from the tax register (morabati). ${ }^{56}$ This would indicate a significant population growth, meaning that Catalan immigration continued during the first half of the fourteenth century until the Black Death. ${ }^{57}$

Unlike Catalonia (particularly the north-eastern 'old Catalonia') and classical feudal Europe, the colonisation of Majorca enabled the creation ex novo of a peasant class subjected to feudal control. The conquest was carefully planned, with agreements beforehand in the Catalan Corts (estates or parliament) between the King of Aragon, the nobility and the cities, as to how land and spoils would be distributed. The distance of five to seven days by boat between the island and the peninsula meant that most of the great nobles (magnats and porcioners) chose representatives to administer their new domains on the island. ${ }^{58}$ This resulted in a rather indirect control over the territory, unlike other feudal colonised areas such as Tortosa ${ }^{59}$ or the Kingdom of Valencia. ${ }^{60}$ The predominant colonisation system in Majorca was for the great nobles to grant in feud or lease the bulk of their properties, only reserving for themselves feudal rights such as jurisdictional rules or manorial rents. This did not lead to the formation of a stratum of large landowners, but rather of lesser feudal knights (cavallers) with medium-size manors called cavalleries. ${ }^{61}$ In Catalonia, these knights were only minor nobility; in Majorca, they were the elite within the resident population, numbering nearly 100.

The Charter of Enfranchisement (Carta de Franquesa) granted in 1232, mentioned at the start of this paper, was of paramount importance in organising many aspects of subsequent social life in Majorca, although its impact has probably been exaggerated by legal-minded historians. ${ }^{62}$ It turned the peasantry into a homogeneous legally 'free' group, among whom the only differences were of a strictly 'economic' order - that is, the quantity (and quality) of the land, money, livestock or slaves they had. Within this institutional framework, a minority of the earliest settlers would soon become a privileged social group in rural areas. For the period prior to the plague the only documents that tell us about the patterns of peasant ownership are the very specific information on 
land tenancy and sale contracts found in the Escrivania de Cartes Reials, a tithe register (delmari) from 1310 and several tax registers (morabatins) kept from 1329 onwards. Some of the tenancy contracts are particularly informative, but the documents of the royal administration provide the most information in this regard, such as the reduction of tasques (11 per cent of the payments to the King, the Church and the landlords) enacted in 1280. The wealth distribution obtained from the morabatins shows a sharp social differentiation and enables us to identify a significant group of rich peasants as well as revealing the uneven spatial distribution of the settlers described above. ${ }^{63}$ This social divide was sharper in the earliest areas of settlement, such as the Raïguer and Muntanya districts, as shown by case studies such as our own of Bunyola, described below, and others. ${ }^{64}$ By the last quarter of the thirteenth century many of those described as 'peasants' were actually big landowners who in some cases, thanks to emphyteusis, controlled, along with the feudal aristocracy, over 90 per cent of the land in a municipality.

The internal process of social differentiation of the Majorcan peasantry, from the conquest to the Black Death, was particularly linked to the impact on land distribution of the uneven repopulation waves described earlier. The 'peasants' that arrived with the conquest can be divided, before the plague, into two broad categories. On the one hand, there were those who took part in the conquest as subordinates to the lords, along similar lines to the conquests of Tortosa and Valencia. ${ }^{65}$ They received land in the first distributions, from both nobles and the king, putting them in a position of privilege with regard to those who came later. Thanks to the initial large availability of land, they received bigger and better holdings either en alou, that is, free of feudal charges (except the tithe) or subject only to very low emphyteutic charges, which usually amounted to only a quarter of the harvest, very low compared with both the peasantry of 'Old Catalonia' and the settlers of 'New Catalonia', the former kingdom of Tortosa. It is doubtful whether this class can be accurately described as a 'peasantry', either in terms of its origins or the role it played in Majorca. It seems more appropriate to consider it as the 'administrators' or 'beneficiaries' of feudal colonisation. Indeed, many did not settle at all, but sold the land they received. ${ }^{66}$ Among those who did settle, their initial wealth enabled them to sublease plots to poor peasants, while their access to money and slaves also enabled them to purchase royal rights. ${ }^{67}$

By contrast, the later settlers who made up the bulk of the population, and were arguably the true 'settlers', could only get access to land through emphyteutic subleases (sotsestabliments) of small plots ceded by the established peasants, either because they arrived when all of the conquered territory had already been parcelled out or because they had become impoverished during the early colonisation and lost their holdings from the initial land distribution (repartiment). ${ }^{68}$ These variegated mosaics of small plots were usually located 
in the vicinity of villages, and often the cultivated areas were too small to attain family self-sufficiency. This group includes the batiats, descendants of freed and converted Muslim captives. Impoverishment was often caused by the fragmentation of families settled after the conquest - although some of them managed to accumulate land and considerable wealth.

How did this fragmentation of Majorcan peasant families occur? According to the traditional Catalan inheritance system, the eldest son was the heir (hereu) and received most of the land, while the other sons left the farm in return for pecuniary compensation (llegitima). This would become one of the chief causes of economic inequalities among families in the later middle ages and early modern period. However, it is not clear whether this inheritance system was the general rule in Catalonia before the thirteenth century - as it has been noted that Gothic law remained in force as late as 1277 in the outskirts of Barcelona. ${ }^{69}$ We should not be surprised if inheritance practices were also blurred in Majorca. Wills from the period differed, from a single heir to a more or less equal division among sons and even other family members. The peasant units, akin to the typical 'nuclear' western family, were the core of the agricultural colonisation of the island, but they often extended to include unmarried adult offspring, in addition to slaves.

Another route to impoverishment was debt. Indebtedness reached chronic proportions in the middle ages, and often meant the simple liquidation of peasant holdings. But under the peculiar conditions of an open colonial frontier, of which Majorca can be considered a prime example, it proceeded in very particular and paradoxical ways. Turnover in land was relatively high on this feudal frontier, not because the market 'worked better', but because for a while the population pressure on land remained lower. In this case settlers fell into debt because of the ease with which they gained control over land, and the ease with which they could acquire loans to purchase even more. Problems arose when their holdings became too large to be worked by the family unit, and where the supply of additional labour was limited (slaves remained scarce and expensive, free labourers were scarce and commanded high wages). Payments to the crown and to nobles, such as tithes or lluïsmes (entry fines on inheritance or sale of land) do not seem to have been a decisive factor in peasant indebtedness here although for most indebted families they were the coup de grace that eventually resulted in the loss of land. ${ }^{70}$

\section{A CASE STUDY OF LANDHOLDING AFTER THE CONQUEST}

Many of the points outlined above can be illustrated through a case study of one district, that of Bunyola (see Figures 2 and 3). We have gathered information on some 800 individuals, both men and women, from 1230 to $1310 .^{71}$ They can be grouped into some 250 families throughout the documented 


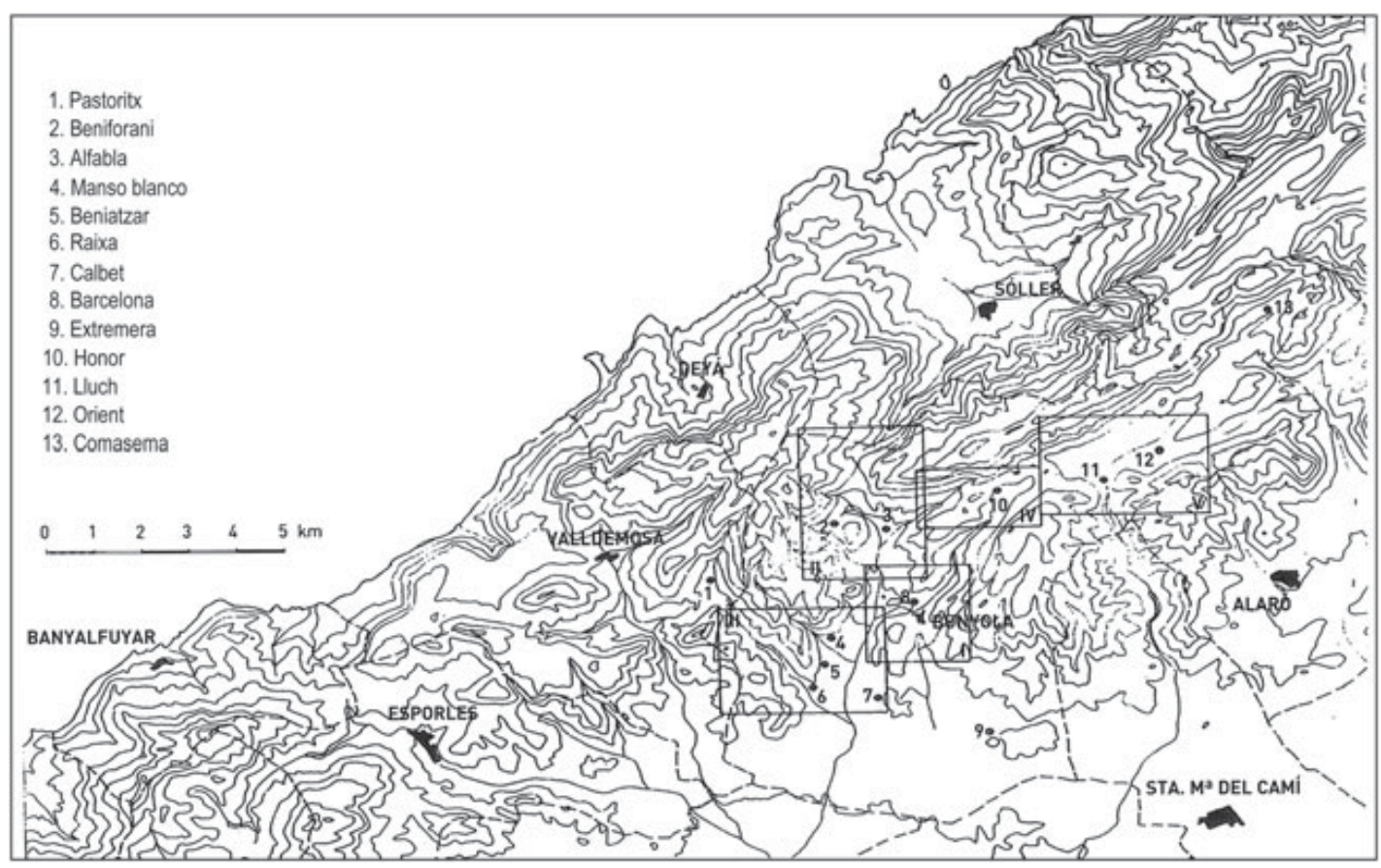

Figure 3. Case study: north-west Majorca. Source: J. Jover and R. Soto, 'De l'agricultura andalusí a la feudal: ¿una ruptura agroecológica? (Mallorca 1230-1350)', in A. Sabio and I. Iriarte eds., La construcción histórica del paisaje en España y Cuba (Zaragoza, 2003), $25-52$.

period. Some stayed longer than others, and only 134 families appear in the registers for the whole period. This figure roughly fits with the 141 families recorded in the morabati of 1329 , but differs from the delmari (tithe register) of 1329 which records only 75 tithe-payers in the parish of Bunyola. Limiting our sample to those families with an above-average presence in the documents leaves 63 family groups ( 24 per cent of the total) who were the most representative of wealthy peasants in the area. Their enduring presence throughout the period sets them apart from the rest. These most documented groups are those who were 'successful' in their settlement process - understanding success here as permanence, although in some cases successful management could also mean arranging a profitable sale of their land in Majorca so as to quickly return home.

These successful families arrived in Majorca at a very early date, which explains how they acquired their lands easily and tended to settle permanently on them. In the mid-fourteenth century Bunyola ranked well above (almost double) the Majorcan average for numbers of well-off peasants, using the following criteria as wealth indicators: those who could afford to keep a horse in 1362, those who held the most valuable plots in 1398, and those having the greatest numbers of slaves in the period 1421-1428.72 These records are far apart in time and from the period after the Black Death when the population 
of Majorca fell, as recorded in the morabatins of 1329 and 1362. Hence, the picture of wealth distribution they provide may not be the same as in earlier periods. Unfortunately, there are no such sources for the thirteenth century and we must infer the socio-economic condition of these families from other documents related to land tenancy, sales, wills, etc. Although these sources are insufficient in number to make up for their fragmentariness, we have nonetheless assembled what can be considered an exceptional dataset, especially considering that, as Christopher Dyer correctly indicates: 'peasants did not leave behind accounts, because they were often illiterate, and such documents meant nothing in a domestic economy in which the bulk of production was for self-consumption'. ${ }^{73}$ Unfortunately, we can never know exactly how much land, livestock or money these families had. The documents did not usually record this information in detail, except when they were useful to identify or locate the land being bought, inherited or leased. Despite all its shortcomings, however, this dataset allows us to outline some general features and trends of Majorcan rural communities during the thirteenth century. ${ }^{74}$

The first point, already mentioned, is the overwhelming predominance of families which had a documented permanence of more than 25 years. Of the 63 families identified above as representative of wealthier peasants, only 2 are documented for less than a 25 -year period. ${ }^{75}$ Given that a documented presence of 25 years is likely to correspond to a longer actual presence, it is difficult to establish a clear dividing line between the first two groups (2550 years and more than 50 years). Nevertheless, of the 41 families that can be documented for over 50 years, 34 of them belong to the core group of 63 leading families who trebled the average length of stay. The remaining seven families were not included in this core group, because their economic activity and wealth did not appear to be significant in the sources. Permanence is not therefore a guarantee of success in terms of achieving wealth and status, though there was a clear association here between the two.

A second point is that only 16 families documented had their land 'in feud' (en alou), either exempt from all feudal taxes or exempt from census tax only. This was identified above as a privilege enjoyed by those who came over in the first phase of the conquest. These leasehold lands exempt from almost all manorial charges were mostly found among the leading families. The bulk of the land was held in emphyteutic tenancy, granted to tenants (either knights or peasants) over generations, in accordance with the notion of an open feudal frontier. Related to this, however, of all family groups documented, 78 had subleased their land out. Although this may be interpreted as a sign of wealth, we must bear in mind that many of these leases were between members of the same family - so they could mean an exchange of plots between neighbours rather than anything else. On the other hand, some family groups that clearly 
failed also subleased land out. It is thus hard to judge 'success' on the basis of tenure.

Other indicators of success are that many inhabitants of this rural area owned property in the City of Majorca, and 12 of them bore the title of 'citizens of Majorca' or 'citizens of Barcelona', indicating the lower ranks of the nobility. There were also five or six knights. Possessing, exploiting or trafficking in Saracen slaves was one of the best indicators of peasant wealth. No fewer than six families (the richest) appear as owners of slaves, and there are more references to slaves in the records for this district. During the thirteenth century the use of slave labour was very intense in Bunyola, as seen in several latifundia such as Beniatzar which specialised in intensive olive monoculture and was ruled as a typical slave plantation. Being crown property, it was divided into 12 parts among large emfiteutes with the usual sale of rights by royal administrators - including a stable team of 12 Saracen slaves. Despite some exceptions, the buyers were not peasants from Bunyola but wealthy citizens of the City directly or indirectly linked to the royal administration. Thus Beniatzar was a very special case. Nonetheless, there was slave labour on other more typical farms of Bunyola. Finally, another good indication of peasant wealth is the acquisition of royal rights. ${ }^{76}$ At least 34 families acquired royal rights during this period.

Vineyards and olive groves were among the most common economic activities of settler families in Majorca. The thirteenth century saw a rapid expansion of vineyards on the island. Bunyola already specialised in olive groves before the conquest, and it experienced only a moderate expansion of this crop.

Settler 'failure' by our criteria is indicated by a lack of visible and durable presence in the documents. However, a clearer indicator, and the main criterion here, is that property was auctioned to pay off debts. At least three of the most important families in our dataset were affected by these auctions before 1273.

Overall, the Bunyola evidence shows that the largest wave of settlers established itself very early on. Before the end of the thirteenth century, within a generation after the conquest, the most important families had already settled there permanently. The success of these well-established peasant families contrasts with the transience of a large number of latecomers, who were more prone to failure. They formed part of another, poorly documented group of land beneficiaries who quickly liquidated their island possessions. Precisely because of the scarce documentation that latecomers generated, we cannot know the specific reasons why they failed. However, the very fact that their footprints vanished so quickly from the historical sources, when the same documents provide us with such an abundance of information on the growing fortunes of the earliest settlers, leads us to believe that the causes of their failure mirrored the reasons behind the latter's success. 


\section{CONCLUDING REMARKS}

The case of the feudal colonisation of Majorca reveals certain peculiarities that have been highlighted so far. The invasion, characterised by the absence of surrender treaties between Christian conquerors and defeated Muslims, allowed the enslavement of nearly all of the surviving Andalusi population. These slaves became part of the spoils of conquest, and were relocated and sold soon after the Christian-feudal dominion was imposed. Fifty years after the conquest they had disappeared from Majorca. While some of them managed to reach freedom (and a minority even converted to Christianity and became part of the new social fabric), many others were sold outside the island.

Shortly after the conquest almost all land had already been distributed among Christian settlers. Those who actually dominated the settlement process came mostly from among the earliest colonisers, who received the most sizable properties, together with the king's and lords' administrators in Majorca. They can be divided into two groups: (1) the nearly 100 knights who held not only manorial rights but a direct domain over land as well (cavalleries); $; 7$ and (2) the wealthy settlers who benefited from the biggest and best lands being distributed among them by the king and the landlords. Both retained the usufruct of most of the land in Majorca, and could decide how the new farming system would be organised.

One or two decades after the conquest, the settlers that continued to arrive in the island found that most of the land had already been distributed. Latecomers were obliged to buy or rent lands from previous settlers. Therefore, colonisation mostly benefited the minor feudal knights, and particularly those earliest settlers who had received large amounts of the land initially parcelled out. Both groups took advantage of their previously acquired lands to rent or sell all or part of them at higher prices. By means of this emphyteutic ownership system, settlers could pay their rent to feudal lords and, at the same time, receive income from the lands they had rented to other, later colonisers. This was how the earliest settlers, those who had obtained the best, most sizeable lands, eventually became Majorca's landowning elite as opposed to later settlers who obtained smaller properties charged with higher rents.

Throughout the thirteenth century there was a continuous inflow of new immigrants seeking to settle on lands rented from landlords, lesser knights and wealthy settlers. Once established in the island, the later settlers would repeat the ownership patterns described above by renting their lands to subsequent immigrants. All this explains the complex hierarchy observed in Majorca only 70 years after the conquest. By 1300, the King of Majorca sought to obtain further income from this situation by creating new settlements in his own feudal domains. Thus, early settlers administering royal properties were then obliged to welcome newcomers who would pay rents and would not be allowed to manage landed property. That late re-colonisation of the island 
and the size of the population recorded 70 years after the conquest seem to indicate that the colonisation process as a whole was very successful in its own terms. The previous Andalusian society in Mayûrqa had disappeared, and had been entirely replaced by the new Christian-feudal society of the Kingdom of Majorca composed primarily of settlers from Catalonia - notwithstanding the considerable number of slaves that initially remained.

Under the rule of the emerging landowner class of the island, but also as a consequence of settler cultural patterns, the new colonisers profoundly reorganised the use of resources in the new territory. They brought to the island their own peninsular feudal farming systems, taking advantage only of Andalusi water infrastructures. This led to a radical change in crop distribution, water use and the role of livestock. Thus we can speak of a profound disruption in the evolving agricultural and forest landscapes, a true socio-ecological transition. For those indigenous people who survived and stayed in the island, either as slaves or freemen, the land they saw was no longer their landscape.

Twenty years were enough to wipe away the entire pre-existing Muslim population, a similar period of time seen in the conquest of other, older Andalusi regions in Castile, Portugal and the Crown of Aragon. Everywhere, the feudal colonisation of al-Andalus meant the end of the Andalusi people itself, either by massacre, ethnic cleansing or cultural assimilation into the new Christian society. In some places the extinction process was sudden (Menorca) or took place in a very short period of time (Majorca), while in others some Muslim communities remained for some time and only disappeared after the Expulsion Act issued in 1609. The final result was the same in all cases: the consolidation of Christian-feudal societies meant the elimination of the autochthonous Muslim population and their replacement by immigrants from northern Iberia, exactly the opposite of what happened in Palestine with the Crusades.

\section{ACKNOWLEDGEMENTS}

This research benefited from the financial support of the international project 'Sustainable farm systems: long-term socio-ecological metabolism in western agriculture', which is a Partnership Grant funded by the Social Sciences and Humanities Research Council of Canada in association with the Spanish project HAR2012-38920-C02-02, 2013-2015. We also wish to thank the editors of the Journal, the anonymous reviewers and Enric Tello for his help in the improvement of this English text.

\section{ENDNOTES}

1 See, for example, A. Santamaría, Ejecutoria del reino de Mallorca, 1230-1343 (Palma, 1990).

2 Arxiu del Regne de Mallorca, Escrivania de Cartes Reials (hereafter ECR), registers 341 to 356 . 
3 T. F. Glick, From Muslim fortress to Christian castle. Social and cultural change in medieval Spain (Manchester, 1995).

4 On the lack of feudal or manorial structures in the peasant communities of Sharq al-Andalus (Valencia and the Balearics), see P. Guichard and P. Bonnassie, 'Les communautés rurales en Catalogne et dans les Pays Valencien (IX milieu-XIV siècle)', in Les communautés villageoises en Europe occidentale du Moyen Age aux temps modernes, Quatrièmes journées internationales d'histoire, Centre culturel de l'abbaye de Flaran, 8-10 septembre 1982 (Auch, 1984), 93-114.

5 The conquest of Majorca was very different from that of the kingdom of Valencia, where a large number of Muslims were allowed to stay according to the surrender treaties. Majorca was violently occupied, and there were no surrender agreements.

6 R. Bartlett, The making of Europe. Conquest, colonization and cultural change, 950-1350 (London, 1993).

7 This was the case of the Armenian and Greek Orthodox Christians of the East, or even of some Roman Christians, such as the Mozárabes in the Kingdom of Toledo, or the Irish and Welsh Celts (Bartlett, Making).

8 J. Torró and P. Guichard, 'Jérusalem ou Valence: la premier colonie d'Occident', Annales: Histoire, Sciences Sociales 55, 5 (2000), 983-1008.

9 A. Peled, 'The local sugar industry under the Latin kingdoms', in S. Rozenberg ed., Knights of the Holy Land: The Crusader Kingdom of Jeusalem (Jerusalem, 1999), 251-57.

10 Bartlett, Making, 148-56.

11 A. Virgili, Ad detrimendum Yspanie. La conquesta de Turtûsa i la formació de la societat feudal (1148-1200) (UAB Barcelona and University of Valencia, 2001); J. Torró, El naixement d'una colònia. Dominació i residència a la frontera valenciana (1238-1276) (University of Valencia, 1999).

12 The oldest exemplar of the Llibre dels Feyts dates from 1343, but it was certainly composed before the death of King Jaume I in 1276.

13 R. Soto, 'La situació dels andalusins (Musulmans i Batejats) a Mallorca després de la Conquesta Catalana de 1230', Mélanges de la Casa de Velázquez 30, 1 (1994), 167-206.

14 According to the Llibre dels Feyts, 20,000 indigenous Saracens died in the capture of the city. See Soto, 'La situació'.

15 Soto, 'La situació'.

16 E. Lourie, 'Free Moslems in the Balearics under Christian rule in the thirteenth century', Speculum 14 (1970), 624-49; and Soto, 'La situació'.

17 For details, see Soto, 'La situació'.

18 Ibid.

19 A. Mas, 'Les Ordinacions de Jaume II: construint un país o administrant el patrimoni del rei?', Lluc: Revista de Cultura i d'Idees 816-817 (May-August 2009), 27-32.

$20 \mathrm{~J}$. Heers, Esclaves et domestiques au Moyen Âge dans le monde méditerrnéen (Paris, 1981).

21 F. Retamero, 'Pautes per a l'estudi dels conreus de secà a Alandalús', in F. Sabaté ed., Els espais de secà. IV Curs Internacional d'Arqueologia (Lleida, 2011), 31-49.

22 See R. Soto ed., Llibre del Repartiment de Mallorca (Palma, 1984).

23 One jovada was about 11.36 hectares.

24 P. Guichard, Al Andalus. Estructura antropológica de una sociedad islámica en Occidente (Barcelona, 1976).

25 Most of the rahals were identified by individuals' names, in contrast to the tribal and clanic names of the alqueries, preceeded by the patronimic 'Beni', indicating that the rahals were single-family farm holdings.

26 H. Kirchner, La construcció de l'espai pagès a Mayûrqa: les valls de Bunyola, Orient, Coanegra i Alaró (University of the Balearic Islands, 1997). 
27 L. Bolens, 'Les methodes culturales au Moyen Âge d'aprés les traits d'agronomie andalous. Tradition et technique' (unpublished PhD thesis, University of Paris, 1972); L. Bolens, Agronomes andalous du Moyen Âge (Geneva, 1981); L. Bolens, 'Al-Andalus, un model de influencias agrarias externas', in J. Morilla, J. Gómez and P. Créssier eds., Impactos exteriores sobre el mundo rural mediterráneo (Madrid, 1997), 125-37; A. M. Watson, 'La conquista islámica y los nuevos cultivos de al Andalus', in Impactos exteriores, 111-23; and A. M. Watson, Agricultural innovation in the early Islamic world: the diffusion of crops and farming techniques, 700-1100 (Cambridge, 1997).

28 M. Decker, 'Plants and progress: rethinking the Islamic agricultural revolution', Journal of World History 20, 2 (2009), 187-206.

29 Kirchner, La construcció.

30 In 1240, only 10 years after the conquest, in an alqueria in Bunyolí (district of Qanat al-Arûsa), the owner paid to the settler 'VIII quarterias annuatim, . scilicet milii et ordei' for sowing (ECR, 343 f. 269).

$31 \mathrm{H}$. Kirchner and R. Soto, 'Les tècniques agràries andalusines i les transformacions posteriors a la conquesta catalana a les Illes Balears', in A. Bonner and A. F. Bujosa eds., Història de la ciència a les Illes Balears, vol. I, L'Edat Mitjana (Palma, 2006), 101-52.

32 K. W. Butzer, F. M. Mateu, E. K. Butzer and P. Kraus, 'Irrigation agrosystems in Eastern Spain: Roman or Islamic origins?', Annals of the Association of American Geographers 75, 4 (1985), 479-509; or more recently, C. Wickham, Framing the early middle ages: Europe and the Mediterranean, 400-800 (Oxford, 2005), 741-59.

33 For Majorca, see mainly M. Barceló, Arqueología medieval en las afueras del medievalismo (Barcelona, 1988); M. Barceló, 'Vespres de feudals. La societat de Sharq al-Andalus just abans de la conquesta catalana', Estudi General 5-6 (1985-1986), 237-49; M. Barceló ed., El curs de les aigües. Treballs sobre els pagesos de Yabisa, 290-633 H./902-1235 dC. (Eivissa, 1997); M. Barceló and H. Kirchner, Terra de Falanis. Felanitx quan no ho era. Assentaments andalusins al territori de Felanitx (Palma de Mallorca-Ajuntament de Felanitx, 1995).

34 Kirchner, La construcció, 30-47.

35 Barceló, El curs de les aigües, 34.

36 Kirchner, La construcció, 25-38.

37 Kirchner and Soto, 'Les tècniques agràries andalusines', 104.

38 M. Bernat, 'Feudalisme i infraestructura artesanal de Madîna Mayûrqa a Ciutat de Mallorca', Bolletí de la Societat Arqueològica Lul.liana 53 (1997), 27-70.

39 See M. Barceló, Sobre Mayûrqa, 50.

40 Kirchner and Soto, 'Les tècniques', 134.

41 Muḥammad Abū'l-Qāsim Ibn Ḥawqal (محمد أبو القاسم بن حوقل) who travelled between 943 and 969 CE, was the author of a famous work, written in 977, called Șūrat al-'Arḍ (صورة الارض 'The face of the Earth'). Lisan ad-Din ibn al-Khatib (1313-1374, Fes, Morocco) was an Arab polymath poet, writer, historian, philosopher, physician and politician from the Emirate of Granada.

42 A. Poveda, 'Algunes hipòtesis sobre l'economia agrària del juźde Jijnû-Bytra a Mayûrqa segons la toponímia àrab i berber', Estudi General 5-6 (1985-1986), 265-73.

43 Abu Abd Allah Muhammad Ibn al-Abbar (1199-1260) was a well-known poet, diplomat, theologian and scholar from Valencia.

44 G. Rosselló, 'Sobre l'estructura socioprofessional de les comunitats islàmiques mallorquines a partir d'una relectura de les fonts documentals', Butlletí de la Societat Arqueològica Lul-liana 58 (2002), 7-28.

45 Kirchner, La construcció, 38-42.

46 A. Mas, 'El procés repoblador a Mallorca durant la primera meitat del segle XIV. Una aportació al seu estudi', Butlletí de la Societat Arqueològica Lul-liana 50 (1994), 167-98; 
A. Mas, 'Petits senyors i grans pagesos. Diferenciació i conflictivitat social a la ruralia de Mallorca (1229-1350)', in M. Barceló, G. Feliu, M. Miquel and S. Sobrequés eds., El feudalisme comptat i debatut. Formació i expansió del feudalisme català (Valencia, 2003), 465502; and M. Barceló, G. Feliu, M. Miquel and S. Sobrequés eds., 'Les Ordinacions, una reforma agraria', in Consell de Mallorca, Jaume II i les Ordinacions de l'any 1300 (Palma de Mallorca, 2002), 19-162.

47 Mas, 'El procés repoblador'.

48 M. Deyà, 'La pañería mallorquina a fines del reino Privativo (1320-1343)', in S. Claramunt ed., El món urbà a la Corona d'Aragó del 1137 als decrets de Nova Planta. XVII Congrés de la Corona d'Aragó (Barcelona, 2003), 345-58.

49 R. Soto, 'L'ordenació de l'espai i les relacions socials a Mallorca en el segle XIII (12291301)' (unpublished $\mathrm{PhD}$ thesis, UAB Barcelona, 1991).

50 R. Rosselló, La Ciutat de Mallorca en el segle XIII (documentari) (Felanitx, 2001).

51 R. Soto, 'Alguns casos de gestió "colonial" feudal a la Mallorca del segle XIII', Estudi General 5-6 (1985-1986), 345-69.

52 Soto, 'La situació', 184; and Barceló and Kirchner, Terra de Falanis, 81-2.

53 A. Mas, 'L'onomàstica com a mitjà per a l'estudi de l'origen dels colons de Mallorca en el segle XIII', in Jornades d'Antropologia i toponímia (UIB/Govern de les Illes Balears, 2002), 65-104; A. Rodríguez, El territori de Pollença sota l'orde del Temple, 1298-1304 (Pollença, 2000).

54 For details, see Soto, 'L'ordenació de l'espai i les relacions socials a Mallorca'. The date of documentation of any sort of transaction (lease, sale, etc.) may have been much later than the date it was actually made, and only reflects its legalisation.

55 R. Soto, 'Colonització i diferenciació pagesa a la Mallorca del segle XIII', in M. Gutiérrez ed., Doctor Jordi Nadal. La industrialització $i$ el desenvolupament econòmic d'España, vol. 1 (Barcelona, 1999), 375-401.

56 Santamaría, Ejecutoria del reino de Mallorca, 276-7.

57 Mas, 'El procés repoblador'.

58 According to J. M. Quadrado, Historia de la conquista de Mallorca (Palma de Mallorca, 1850).

59 A. Virgili, Ad detrimendum Hispaniae.... La conquesta de Turtûsha i la formació de la societat feudal, 1148-1200 (Valencia, 2002).

60 Guinot, Els fundadors; and J. Torró, El naixement d'una colònia: dominació i resistència a la frontera valenciana, 1238-1276 (Valencia, 1999).

61 P. Montaner, 'Les cavalleries mallorquines (segles XIII-XVIII)', in N. Sales, P. Montaner, I. Moll and R. Garrabou, Terra, treball I propietat: classes agràries I règim senyorial als Països Catalans (Barcelona, 1986), 42-65.

62 R. Soto i Company, 'Conquesta, repartiment i colonització de Mallorca durant el segle XIII: un estat de la qüestió', Anuario de Estudios Medievales 26, 2 (1996), 606-46.

63 Mas, 'El procés repoblador'.

64 Soto, 'Colonització i diferenciació pagesa', 375-401; and Rodriguez, El territori de Pollença.

65 Studies carried out on processes of conquest and repopulation as different spatially and chronologically as Tortosa or Valencia have noted the presence of these 'professionals of the Reconquista'. See Virgili, Ad detrimendum Hispaniae. ..; and Torró, El naixement d'una colònia.

66 See Quadrado, Historia de la conquista; and R. Soto, 'Introducció', in Còdex Català del Llibre del Repartiment de Mallorca (Palma de Mallorca, 1984).

67 In any case, some of these beneficiaries could be considered as the locatores described above, in a very different context, as seen in Bartlett, Making. This could be the case of the procurator Duran Coc. Besides being an important beneficiary, he also let lands to several men of the city of Barcelona. See R. Soto, 'Repartiment i repartiments', in M. Sánchez (coord.), De al-Andalus a la sociedad feudal: los repartimientos bajomedievales (Barcelona, 1990), 1-51. 
68 For the Repartiment (distribution of lands between nobles and settlers), see Soto, 'Introducció'.

69 Ll. Tó, Familia i hereu a la Catalunya nord-oriental (segles X-XII) (Barcelona, 1997).

70 Lluïsme or laudemio is the part that the lord received from the price of a sale.

71 For details, see Soto, 'Colonització i diferenciació pagesa', 375-401, which is based on the sources quoted in note 2 .

72 G. Jover, 'Societat rural i desenvolupament econòmic a Mallorca. Feudalisme, latifundi i pagesia, 1500-1800' (unpublished $\mathrm{PhD}$ thesis, University of Barcelona, 1997).

73 C. Dyer, Standards of living in the later middle ages: social change in England c. 1200-1520 (Cambridge, 1989), 109.

74 These conclusions are mainly based on Soto, 'Colonització i diferenciació pagesa', 375-401.

75 Of these 63 families, 34 are documented for more than 50 years, 27 between 25 and 50 years, and 2 for under 25 years. See Soto, 'Colonització I diferenciació pagesa', 393.

76 The royal rights (drets reials) were taxes on different products (wheat, wine, oil, cattle, vegetables, etc.) or on social groups (Jews, free Muslims, etc.) and included the rights of the king. The royal rights on products were collected locally. These rights were not directly collected by royal officials; instead, the right to collect them was sold at auction.

77 G. Jover and R. Soto, 'Els dominis feudals a la Mallorca baixmedieval (segles XIII-XVI)', Revista de Història Medieval 8 (1997), 217-74.

\section{FRENCH AND GERMAN ABSTRACTS}

Colonisation féodale et transition socio-écologique à Mayûrqa (Majorque musulmane) au treizième siècle

Il faut compter la colonisation féodale de l'île de Majorque, traditionnellement considérée comme faisant partie de la Reconquista espagnole, dans le processus général d'expansion féodale en Europe. Le peuplement de l'île constituait alors une société musulmane, et non féodale. La conquête menée par des seigneurs catalans signifiait qu'était imposée une nouvelle structure de classe féodale, allant de pair avec une utilisation nouvelle des ressources naturelles sur le terrain conquis. Nous résumons la structure et l'évolution des trois principales composantes de cette féodalité imposée par le haut: les populations musulmanes conquises et réduites en esclavage, les colons catalans et le tout nouveau paysage agricole qu'ils ont créé.

Feudale Kolonisation und sozio-ökologische Transition in Mayûrqa (muslimisches Mallorca) im 13. Jahrhundert

Die feudale Kolonisation Mallorcas, die herkömmlicher Weise nur als Teil der spanischen Reconquista angesehen wird, muss in den größeren Zusammenhang der feudalen Expansion in Europa eingeordnet werden. Die Insel war zunächst von Leuten bewohnt, die in einer muslimischen und nicht in einer feudalen Gesellschaft lebten. Die Eroberung durch katalanische Grundherren bedeutete, dass das unterworfene Land nicht mit einer neuen feudalen Klassenstruktur, sondern auch mit neuen Nutzungsformen der natürlichen Ressourcen überzogen wurde. Wir stellen die Zusammensetzung und Entwicklung der drei Hauptbestandteile dieses von oben übergestülpten Feudalismus dar: der eroberten und versklavten muslimischen Bevölkerung, der katalanischen Siedler und der völlig neuen agrarischen Kulturlandschaft, die sie schufen. 